\title{
Biological Effects Produced by Intense Pulsed Light (Xe-Cl) on the Cartilage of the Tongue Chick Embryo Using Various Filters
}

\author{
Efectos Biológicos Producidos por la Luz Pulsada Intensa (Xe-Cl) sobre \\ el Cartílago Lingual del Embrión de Pollo Usando Diversos Filtros
}

Avila, R. E.; Samar, M. E.; Juri, H.; Femopase, G. A.; Hidalgo, M.; Ferrero, J. C.; Rinaldi, C.; Fonseca, I. \& Juri, G.

AVILA, R. E.; SAMAR, M. E.; JURI, H.; FEMOPASE, G. A.; HIDALGO, M.; FERRERO, J. C.; RINALDI, C.; FONSECA, I. \& JURI, G. Biological effects produced by Intense pulsed light $(\mathrm{Xe}-\mathrm{Cl})$ on the cartilage of the tongue chick embryo using various filters. Int. J. Morphol., 27(4):1003-1008, 2009.

SUMMARY: The Laser used correctly in the medical practice offers clear advantages compared with traditional therapies. The improvement and even the elimination of many significant skin lesions can be achieved with reduced risks to patients. However, it is important to keep security measures and understand the possible effects on an experimental model. The chick embryo is a good model to evaluate the direct effects of non-ionizing radiation for its easy handling and availability. The purpose of this communication is to show our histological findings in organs of the chick embryo with and without protective barrier to be subjected to radiation excimer. We used the following issuers: intense pulsed light (excimer Xe-Cl laser of $308 \mathrm{~nm}$ wavelength). It was irradiated embryos through an open window on eggshells. Aseptically the eggs were kept for 24 hours in an incubator. The protective barriers were used with and without colored glass, latex, cellophane, paper, polycarbonate of different colors and thicknesses. The most outstanding results, with no barrier and barriers with transparent and green were intense marked congestion in capillaries, edema and focus the necrosis. We concluded that the tissue changes observed are consistent with possible side effects of these radiations fototérmicos we warned about possible side effects when they are applied indiscriminately. We believe it is important to explore different means to safeguard the safety of operators and patients.

KEY WORDS: Biological effects; Intense pulsed light (Xe-Cl); Cartilage; Tongue; Chick embryo.

\section{INTRODUCTION}

Non ionizing radiations are part of natural light and produce both beneficial and malignant effects, depending on several factors, such as exposure, wavelength and intensity. In addition those radiations can be also generated in artificial form in a wide range of wavelengths and with different optical properties (Chan et al., 2007).

Of special relevance in many aspects of the human activity is the ultra-violet region of the spectrum, which comprises wavelengths in the range $500-100 \mathrm{~nm}$. They are usually classified according to their wavelengths in three types, denominated UVA (400-315 nm), UVB (315-280 nm) and UVC (280-100 nm). Radiation in these regions can be produced by a number of devices, from the ordinary low energy continuous lamp to high energy superradiant pulsed laser.
The laser is a light source that produces coherent electromagnetic radiating energy. A widely used laser in medicine is the $\mathrm{Xe}-\mathrm{Cl}$ excimer laser, obtained from the emission of electronically excited $\mathrm{XeCl}$, whose spectrum shows two main emission bands, cantered at $308 \mathrm{~nm}$ and $367 \mathrm{~nm}$. Although their relative intensities depend of the conditions of the excitation, emission at $308 \mathrm{~nm}$ is much more intense. Commercially available $\mathrm{Xe}-\mathrm{Cl}$ lasers operate at $308 \mathrm{~nm}$ with pulses of $10-20 \mathrm{~ns}$, energies up to $1 \mathrm{~J}$ and variable repetition rates from 1 to $500 \mathrm{~Hz}$ o even more (Spencer \& Hadi, 2004).

In addition to the laser, from 1995 it has also been available a device that emits at $308 \mathrm{~nm}$, called intense pulsed light (IPL) which is basically a Xe-Cl lamp that has proved to be a useful tools for the treatment of the changes of the 
skin. The IPL provides high energy pulsed excitation consisting of $85 \%$ of ultraviolet radiations UV B and $15 \%$ of radiations UV A. This technology is also known as "Photoderm". Although the active medium of this lamp is also $\mathrm{XeCl}$, the emission is polychromatic but also non coherent; therefore is not a laser. However, the use in medicine and the risks associated with it are comparable to the medical lasers of the high energy (class $3 b$ and 4) and therefore their use should be subject to the same security guidelines (Reed et al., 1994; Nahavandi et al., 2008).

The IPL is used in a similar way to the excimer laser in the treatment of various pathologies of the skin: psoriasis, vitiligo, etc. Clinically it is also used to stimulate the regeneration of the cartilage in degenerative processes. It has been postulated that its action is based on the activation of the cell division, collagenous and elastic fibers formation, regeneration of blood vessels, cicatrisation of bone tissue and reepithelization of damaged tissue (Moseley, 1994; Garrigo \& Valiente, 1996; Baumanna et al., 2006; Town et al., 2007).

Nevertheless, there are some discrepancies in results obtained with experimentation animals on the medical use of not-ionizing radiations (Reed et al.). In a previous study, we irradiated chick embryos and new born chickens with $\mathrm{He}-\mathrm{Ne}$ laser, infrared and ultraviolet radiation, finding post irradiation histopathologic changes (Avila et al., 1994; Reed et al.; Samar et al., 1993).
However, the biological effect of the $308 \mathrm{~nm}$ IPL has not been investigated using the oral cavity of chick embryos as sensor.

Therefore, it seems important to study the optical characteristics of the filtered and unfiltered light emitted by the Intense pulsed light $(\mathrm{Xe}-\mathrm{Cl})$ and its biological effects using the lingual cartilage of the chick embryo as a sensor, in order to obtain information about security measures on patients and medical staff.

\section{MATERIAL AND METHOD}

An scheme of the experimental set up used to study the effects of radiation on different tissues of chick embryos is shown in Fig. 1. The system consists of a commercial excimer Xe-Cl laser source of intense pulsed light $(50 \mathrm{~mW} /$ $\mathrm{cm} 2$ ) of $308 \mathrm{~nm}$ (DEKA model Excilite), whose emission was characterized in this work (Fig. 2), a set of filters whose absorption spectra are presented in Fig. 3, a spectrometer (E1) Ocean Optics model HR4000 (resolution $0.02 \mathrm{~nm}$, spectral range $200-1100 \mathrm{~nm}$ ) that was used to characterize the filtered and unfiltered emission of the LPI system used in this work, a detector to measure the energy (E2) Scientech model 756 and a sensor (E3) model 362 of full range (200 $\mathrm{nm}$ to $1 \mathrm{~mm}$ ). With this system we measured the spectra of the excimer light transmited by the filters and the total

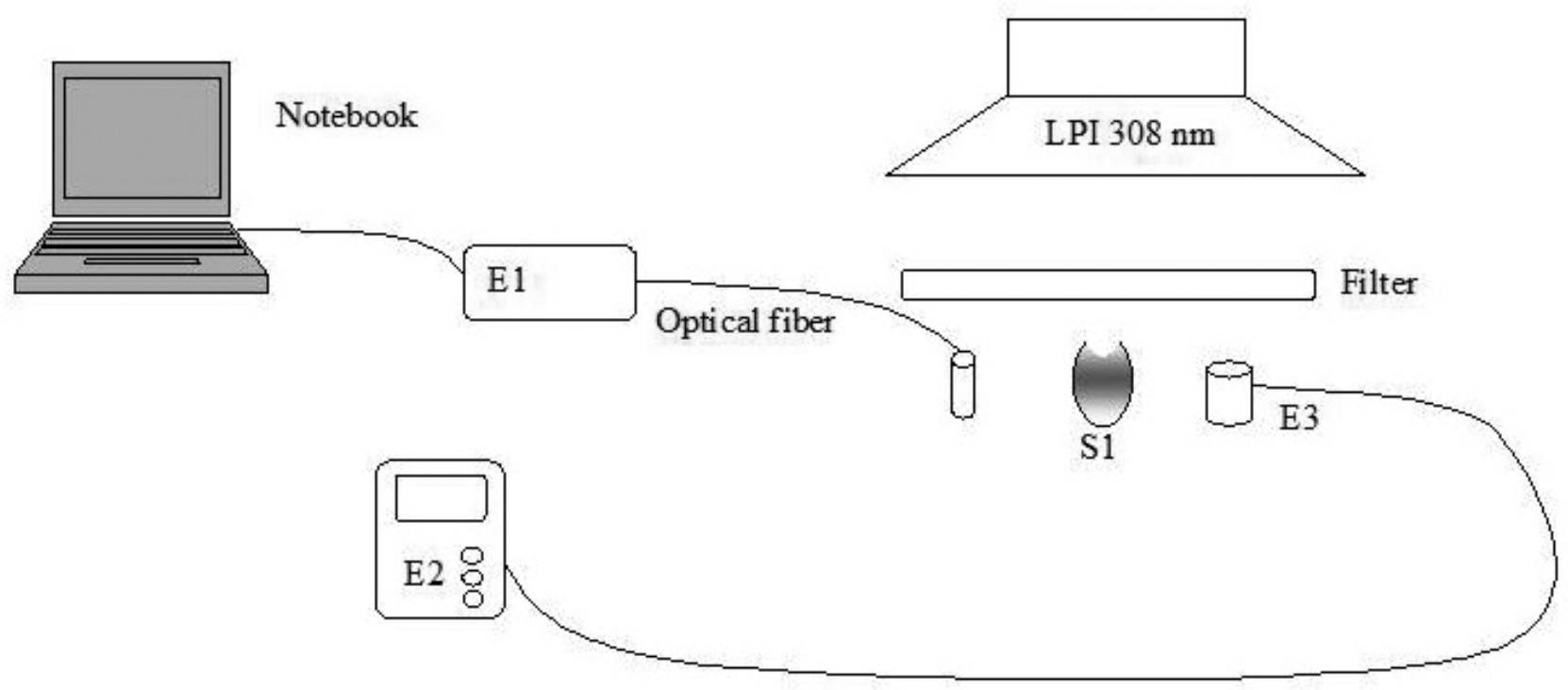

Fig. 1. Scheme of the experimental setup: E1: Spectrometer Ocean Optics HR4000, E2: Energy meter, E3: Energy sensor, S1: sample (egg), LPI: IPL source(308 nm). 


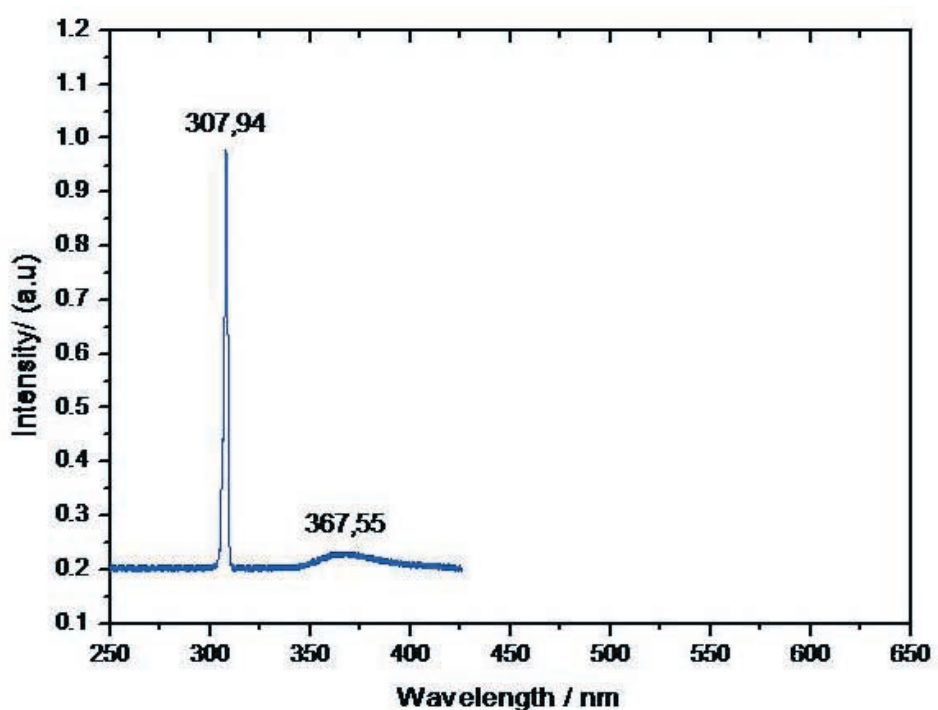

trol were not irradiated. All the eggs, control and test, were incubated aseptically at $37^{\circ} \mathrm{C}$ during 24 hours post-irradiation.

The samples extracted were fixed in Bouin's fluid and processed according to routine histological techniques, stained with hematoxyline and eosin and histochemical technique : PAS, for the glycoprotein demonstration; Alcian blue at $\mathrm{pH}$ 2,5 and 1,0 for the demonstration of glycosamineglycans: Toluidine blue at $\mathrm{pH} 3,8$ to demonstrate basophilic and alcohol-resistant metachromatic substances.
Fig. 2. Emission spectrum ot the Xe-Cl lamp(LPI).

incident energy by unit surface in $\mathrm{mJ} / \mathrm{cm}^{2}$, on each sample with the different filters used.

As a biological sensor we used 15 chick embryos with 15 days of "in ovo" development, separated in two groups. All the eggs had a small portion on the shell above the air cell and the corresponding outer membrane removed. This remotion of a portion of the membrane was necessary because of its optical properties, as explained below. The test group consisted of 10 eggs that were irradiated thorough this window, while the 5 eggs of the con-

\section{RESULTS}

The optical characteristics of the light emitted by the $\mathrm{XeCl}$ lamp were determined using the experimental equipment schematically shown in Fig.1. A typical emission spectrum from this lamp obtained with this set up is shown in Fig 2. Integration of the spectrum showed that it was composed by $85 \%$ of UVB radiation, centered at $308 \mathrm{~nm}$ and $15 \%$ of UVA light, centered at $367 \mathrm{~nm}$. Therefore the biological effects found in the chicken embryos are mainly due to the photons of $308 \mathrm{~nm}$, and consequently they should be similar to those expected from the irradiation with a Xe$\mathrm{Cl}$ laser in comparable conditions.

Table I. The absorption spectra of filters, in the $240-650 \mathrm{~nm}$. Intensity of the light from the Xe-Cl lamp (IPL) transmitted through the different filters, measured at $30 \mathrm{~cm}$ from the lamp.

\begin{tabular}{lccccc}
\hline \multicolumn{1}{c}{ Filter } & Exposure time /s & $\begin{array}{c}\text { Transmitted Intensity } \\
(\mathrm{mW})\end{array}$ & $\begin{array}{c}\text { Transmitted } \\
\text { Fluence }\left(\mathrm{mJ} / \mathrm{cm}^{2}\right)\end{array}$ & $\begin{array}{c}\text { Filter } \\
\text { absorbance }\end{array}$ & $\begin{array}{c}\text { Filter transmittance } \\
(\%)\end{array}$ \\
\hline None & 20 & 18.1 & 147.50 & 0.00 & 100 \\
F1: Green acetate & 20 & 0.46 & 3.74 & 1.59 & 2.5 \\
F2: Blue acetate & 20 & 0.00 & 0.00 & 2.00 & 0.0 \\
F3: Clear acetate & 20 & 0.00 & 0.00 & 2.00 & 0.0 \\
F4: Yellow acetate & 20 & 0.00 & 0.00 & 2.00 & 0.0 \\
F5: Orange acetate & 20 & 6.70 & 54.60 & 0.43 & 37.0 \\
F6: Red Cellophane & 10 & 3.29 & 13.40 & 1.04 & 9.1 \\
F7: Clear Cellophane & 10 & 18.0 & 73.34 & 0.30 & 49.7 \\
F8: Yellow Cellophane & 10 & 2.2 & 8.96 & 1.21 & 6.07 \\
F9: Blue Cellophane & 10 & 0.48 & 1.95 & 1.87 & 1.32 \\
F10: Orange Cellophane & 10 & 9.2 & 37.50 & 0.60 & 25.0 \\
F11:Green Cellophane & 20 & 5.25 & 42.8 & 0.53 & 30.0 \\
\hline
\end{tabular}


In order to analyze the effect of partial filtering the light from the excimer lamp used various filters of acrylic (Ac) and cellophane (Cel). The absorption spectra of these filters, in the $240-650 \mathrm{~nm}$ region are presented in Table I.

\section{Biological effects on the lingual cartilage of the chick} embryos. We will briefly describe the main results obtained in experiments with the unfiltered light from the $\mathrm{Xe}-\mathrm{Cl}$ emission and with the filters that presented the largest transmittance at that wavelength $(308 \mathrm{~nm})$.

Regarding the control group (Fig. 3 A), the tongue of the chick embryos present a central hyaline cartilaginous axis with abundant isogenic groups of chondrocytes and a homogenous stained matrix. This cartilage is surrounded by a mucosa with squamous stratified epithelium and connective tissue with well developed glands, which extends laterally from the proximal region of the organ (seromucous) towards the distal part (mucous).

With respect to the test group, we present a few representative results, obtained with three different filters. The most relevant findings consisted in degenerative changes in the cartilage with pleomorphic chondrocytes, which in some cases presented nuclei with progressive chromatin condensation (hyperchromasia) and in others vacuolated nuclei, with macro and anisokaryosis. These results are presented in Fig 3- B and correspond to irradiation using filter F5 (Orange acetate).

In samples corresponding to irradiation though filter F10, we observed chondrocytes with pycnotic and hyperchromic nuclei with poorly defined limits (apoptosis) and in some cases total destruction. The cartilaginous matrix presented a reduced stained affinity (Fig.3-C).

The example shown in Fig 3- D corresponds to a study green using filter. Here we observed distal glandular necrosis, leucocyte infiltrate, thickening of the blood vessel walls to the expense of the tunica media, with perivascular edema in the subepithelial and perichondrium connective tissue.

Fig. 3. A: Control, cartilage is in center of the tongue with hematoxylin and eosin stain, $5 \mathrm{X}$. B: Irradiation using the orange acetate filter. In the upper part it is observed the hyaline cartilage with degenerative changes: pleomorphic chondrocytes, nuclei with progressive condensation of the chromatin (hipercromasia), and vacuolated nuclei, with macro and anisokaryosis. Lower part: mucous glands with leucocyte inflitrate and necrosis. Hematoxylin and eosin stain. $10 \mathrm{X}$.
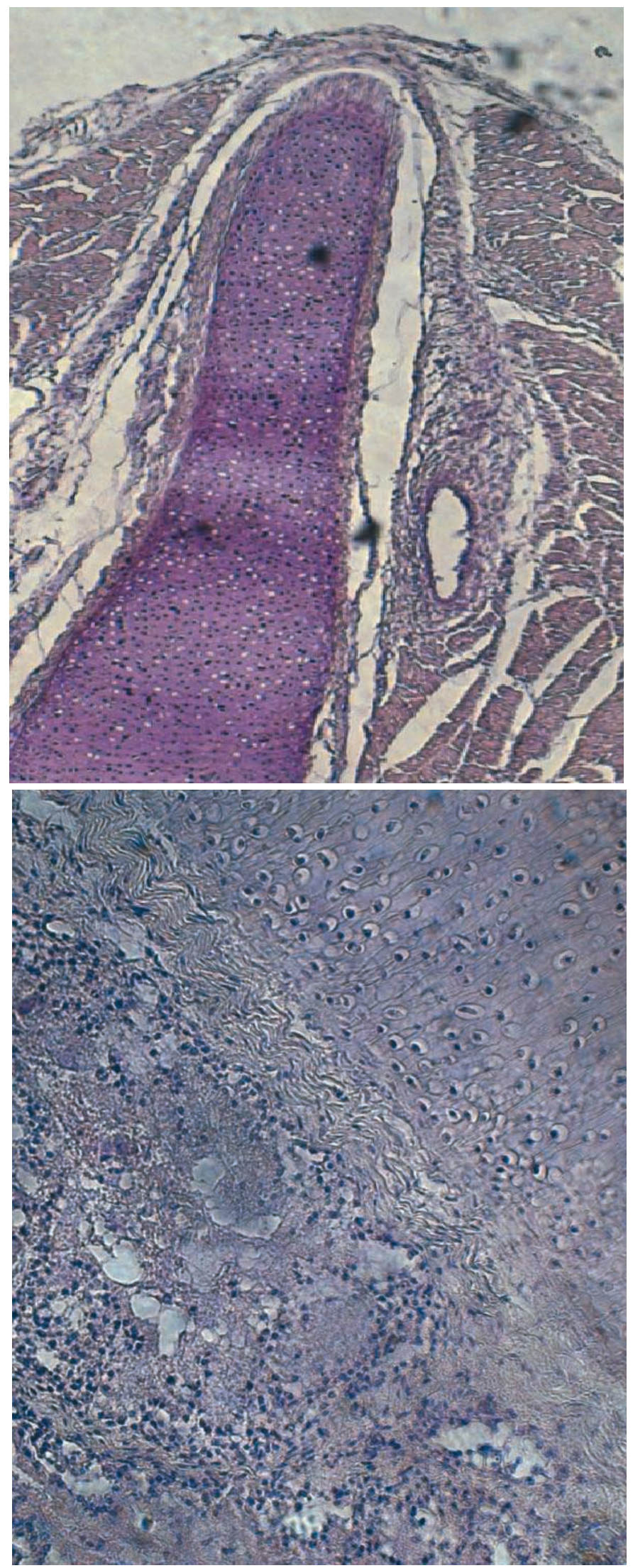

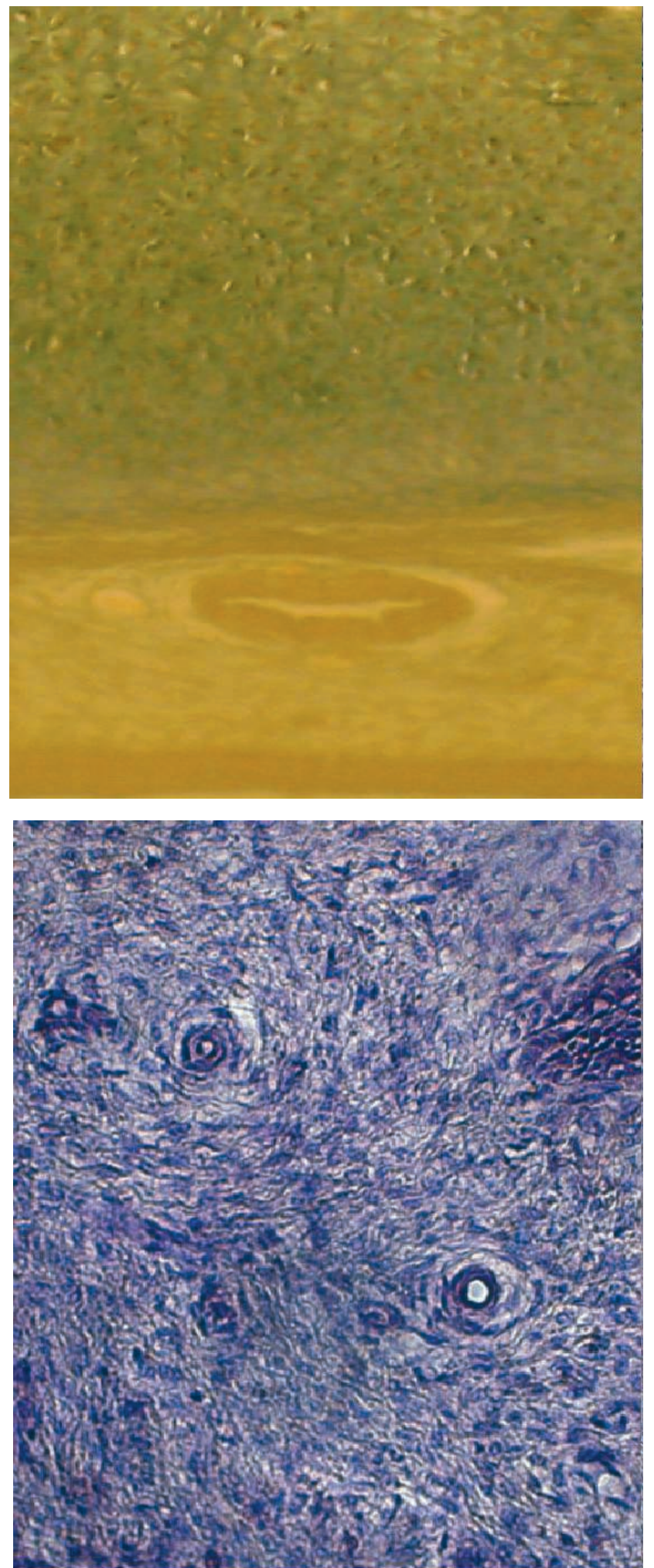

C: Test sample. Irradiation using the orange acetate filter In the superior part the cartilage presents a matrix with decreased tintorial affinity. Alcian blue at $\mathrm{pH} 2.5,10 \mathrm{X}$. D: Test sample. Irradiation using the green cellophane filter. Blood vessels with thickening of its interstitial wall and edema. Hematoxylin and eosin stain. $40 \mathrm{X}$.

\section{DISCUSSION}

The laser and other high energy sources of light are becoming widely used in the medical practice to treat a variety of problems. At the same time, more concern appears about the undesirable effects that they could have on human health. As a consequence programs related to the security measures in its use are spreading quickly, as well as governmental regulations. Many nations have published security norms on laser, most of them in agreement with the norms of the International Electrotechnical Commission (IEC). The maximum allowed limits of exposition used in international standards of security of the CEI are based on guidelines of the International Commission on Non-Ionizing Radiation Protection (ICNIRP). Norm CEI 825-1 (1993) it prevails for the manufacturers. However, also it offers some limitations oriented on the security for users. All the commercial lasers must exhibit the indicated classification of risk (Davey et al., 1981; Moseley; Takac \& Stojanovic, 1998; Town et al.; Nahavandi et al.).

The laser, when it is used correctly, offers clear advantages in comparison with the traditional therapies (Gerber et al., 2003). The improvement and even the significant elimination of many cutaneous injuries they are possible to be obtained with reduced risks for the patient. Nevertheless it is important to keep safety measures and to know the possible effects in an experimental model.

To our knowledge, this is the first report on the biological effects of the $308 \mathrm{~nm}$ radiation of intense pulsed light from excimer $\mathrm{Xe}-\mathrm{Cl}$ in buccal cavity of chick embryo. For this reason we investigated the histopathologyc changes produced in the tongue of chick embryos, specially in the cartilage.

The Xe-Cl IPL system used in this work resulted in histological alterations in the tissue of chick embryos, demonstrating that his procedure by its simple methodology and availability can be used as a model to study the effect of non ionizing radiation on human health. In addition, the high energy, highly monochromatic emission at $308 \mathrm{~nm}$ provided by this lamp suggests that these effects could be similar to those produced by the excimer $\mathrm{Xe}-\mathrm{Cl}$ laser, operating at the same wavelength. It should be noted that the IPL is routinely used for the treatment of several skin problems, and therefore, the spectroscopy characterization reported here indicates that care should be exercised when using this kind of light sources. The filters used acted as attenuators of the light intensity and provide information about the optical properties of materials to be used as protective barriers for patients and medical staff, when employing this and related techniques. 
These results are simmilar to those previously described on the effect of ultraviolet, infrared and $\mathrm{He}-\mathrm{Ne}$ radiation (Samar et al.; Avila et al.). Baumanna et al. studied the influence of radiations laser in human chondrocytes using different wavelengths $(690 \mathrm{~nm}$ diode laser and Nd: YAG tuned to $1064 \mathrm{~nm}$ ), power densities and exposure time. Under certain experimental conditions they observed an increase in the synthesis of the matrix in cartilage cultures from 36 patients. They also reported, using a very high intensity but constant energy, a $28 \%$ reduction of the rate of synthesis of the matrix.

One concludes that these tissue modifications they are compatible with collateral photothermal effects of these radiations that notice on possible adverse effects to the dose and time to us used experimentally.

AVILA, R. E.; SAMAR, M. E.; JURI, H.; FEMOPASE, G. A.; HIDALGO, M.; FERRERO, J. C.; RINALDI, C.; FONSECA, I. \& JURI, G. Efectos biológicos producidos por la luz pulsada intensa (Xe-Cl) sobre el cartílago lingual del embrión de pollo usando diversos filtros. Int. J. Morphol., 27(4):1003-1008, 2009.

RESUMEN: El láser utilizado correctamente en la práctica médica ofrece claras ventajas cuando se compara con las terapias tradicionales. La mejoría e incluso la eliminación significativa de muchas lesiones cutáneas se pueden lograr con riesgos reducidos para los pacientes. Sin embargo, es importante guardar medidas de seguridad y conocer los posibles efectos en un modelo experimental. El embrión de pollo es un buen modelo para evaluar los efectos directos de radiaciones no ionizantes por su fácil manipulación y disponibilidad. El objetivo del presente trabajo es comunicar los cambios histopatológicos en órganos del embrión de pollo con y sin barrera de protección al ser sometido a radiación excimer. Se utilizó el siguiente elemento emisor: luz pulsada intensa (Xe-Cl excimer laser de $308 \mathrm{~nm}$ de longitud de onda. Se irradiaron los embriones a través de una ventana abierta en la cáscara del huevo. Los huevos fueron mantenidos asépticamente por 24 hs en una incubadora. Las barreras de protección utilizadas fueron vidrio con y sin color, latex, celofán, papel, policarbonato de diferentes colores y espesores. Los resultados más sobresalientes, sin barrera y con barreras transparentes y de color verde fueron: intensa vasocongestión, edema y focos de necrosis. Se concluye que las modificaciones tisulares observadas son compatibles con posibles efectos fototérmicos colaterales de estas radiaciones los que nos advierten sobre posibles efectos adversos cuando las mismas se aplican indiscriminadamente. Creemos que es de importancia estudiar los diferentes medios que permitan resguardar la seguridad de los pacientes y operadores.

PALABRAS CLAVE: Efectos biológicos; Luz pulsada intensa (Xe-CI); Cartílago; Lengua; Embrión de pollo.

\section{REFERENCES}

Avila, R. E.; Samar, M. E.; De Fabro, S. P.; Leguina, M. \& Juri, H. $\mathrm{O}$. Histologic changes produced by non ionizing radiation in the chick embryo. Rev. Fac. Cien. Med. Univ. Nac. Cordoba, 52:27-30, 1994.

Baumanna, M.; Bjorn, J.; Rohdec, E.; Bindigd, U.; Mullerc, G. \& Schellera, E. Influence of wavelength, power density and exposure time of laser radiation on chondrocyte cultures - An in-vitro investigation. Med. Laser Appl., 21:191-8, 2006.

Chan, H. H.; Yang, C. H.; Leung, J. C.; Wei, W. I. \& Lai, K. N.An animal study of the effects on p16 and PCNA expression of repeated treatment with high-energy laser and intense pulsed light exposure. Lasers Surg. Med., 39(1):8-13, 2007.

Davey, J.; Diffey, B. L. \& Millar, I. A. Eye protection in psoralen photochemotherapy. Br. J. Dermatol., 104:295-300, 1981.

Garrigo, M. \& Valiente, C. Efectos biológicos de la radiación láser de baja potencia en la reparación hística. Rev. Cubana Estomatol., 33(2):60-3, 1996.

Gerber, W.; Arheilger, B.; Ha, T. A.; Hermann, J. \& Ockenfels, H. M. Ultraviolet B 308-nm excimer laser treatment of psoriasis: a new phototherapeutic approach. Br. J. Dermatol., 149:1250-8, 2003.

Moseley, H. Ultraviolet and laser radiation safety. Phys. Med. Biol., 39:1765-99, 1994.
Nahavandi, H.; Neumann, R.; Holzer, G. \& Knobler, R. Evaluation of safety and efficacy of variable pulsed light in the treatment of unwanted hair in 77 volunteers. J. Eur. Acad. Dermatol. Venereol., 22(3):311-5, 2008.

Reed, S. C.; Jackson, R. W.; Glossop, N. \& Randle, J. An in vivo study of the effect of excimer laser irradiation on degenerate rabbit articular cartilage. Arthroscopy, 10(1):78-84, 1994.

Samar, M. E.; Avila, R. E. \& Juri, H. Histological changes produced by He-Ne laser on different tissues from chick embryo. J. Clin. Laser Med. Surg., 11:87-9, 1993.

Spencer, J. M. \& Hadi, S. M. The excimer lasers. J. Drugs Dermatol., 5:522-5, 2004.

Takac, S. \& Stojanovic, S. Classification of laser irradiation and safety measures. Med. Pregl., 51:415-8, 1998.

Town, G.; Ash, C.; Eadie, E. \& Moseley, H. Measuring key parameters of intense pulsed light (IPL) devices. J. Cosmet. Laser Ther., 9(3):148-60, 2007.

Correspondence to:

Prof. Dr. Rodolfo E. Avila

Departamento de Biología Celular, Histología y Embriología Fac. de Ciencias Médicas, Universidad Nacional de Córdoba Calle Catamarca 1546 (500)

Córdoba - ARGENTINA

Email: ravila@cmefcm.uncor.edu

Received: 07-06-2009 Accepted: 23-08-2009 